\title{
Promoting Bokashi as an Organic Fertilizer in Indonesia: A Mini Review
}

\author{
Sahta Ginting* \\ Department of Soil Science, Halu Oleo University, Indonesia
}

Submission: September 12, 2019; Published: September 26, 2019

*Corresponding author: Sahta Ginting, Department of Soil Science, Faculty of Agriculture, Halu Oleo University, Kendari, Indonesia

\begin{abstract}
Crop production in agricultural dry land areas of Indonesia is limited by low soil fertility. Bokashi amendment to this soil is considered to be the key solution to overcome the problem for continuing sustainable crop productions. A number of research results in Indonesia have been shown to have beneficial effects in using Bokashi. It is believed that Bokashi is a technology which could change agricultural management to more natural farming system than chemical based practices. Accordingly, it may improve the soil fertility and plant production. Moreover, adopting the bokashi amendments in this area is regarded to be more adaptable to farmers and abundance locally raw material resources.
\end{abstract}

Keywords: Soil fertility; Crop production; Effective microorganisms; Bokashi; Organic fertilizer

\section{Introduction}

A major constraint to crop production in dry land of agricultural areas in Indonesia is due to the low of soil fertility. Utilization of Bokashi as an organic fertilizer has been promoted to overcome this problem. Practical advantages of the use organic fertilizers may include quick preparation, low cost, locally available materials, and adaptable to farmers. Bokashi is a technology which converting the use of chemical-based farming systems to a more sustainable agriculture by which improving and maintaining the fertility of soil. The aim of this paper is to short review the use of Bokashi in improving soil fertility and crop production.

\section{Technology of Bokashi}

Bokashi is a system of odorless composting by selected "effective microorganisms" (EM). This system relies on fermentation rather than putrefaction. Bokashi is made by using an organic material which inoculated with the EM. The concept of EM-Bokashi was discovered and developed by Professor Teruo Higa in 1980s at the University of the Ryukyus, Japan [1].

The EM consists of mixed cultures of beneficial and naturally occurring microorganisms applying as inoculants to increase the microbial diversity in soils and plants. Some findings have shown that the inoculation of EM- Bokashi cultures to the soil-plant ecosystems improve soil fertility, growth and yield of crops. The EM contains up to 80 different species belonging to five primary groups of microorganisms, such as predominant populations of lactic acid bacteria (Lactobacillus plantarum, L. casei, L. fermentum, L. salivarius, L. delbrueckii) and yeasts (Saccharomyces cerevisiae), smaller numbers of photosynthetic bacteria (Rhodobacter sphaeroides, R. capsulatus and Rhodopseudomonas palustris), actinomycetes and mold fungi [2-4]. All of these microorganisms are mutually compatible. Organic materials as the raw materials are frequently derived from: crop residues, organic materials of plant, oil cakes, food processing residues and mineral resources which are mixed and incubated with EM to form Bokashi [1,5-6].

Bokashi have been shown to increase plant nutrient uptake, growth, and yield via different basic mechanisms such as changes in soil structure, nutrient solubility, root growth and morphology, plant physiology, and symbiotic relationships [4,7]. Although the exact mechanism of Bokashi in relation to soil-plant systems is remain controversial [8,4], many farmers in Asian countries including Indonesia have adopted the Bokashi technology [9-12].

\section{Effects of Bokashi to soil and plant growth}

Bokashi is a soil fertility technology amendment in farming systems. This technology can be applied to ameliorate the soil properties to a better condition for plant growth and production $[4,12]$. A number of positive effects of the Bokashi applications on improving soil fertility and plant growth as well as reducing the use of inorganic fertilizers have been reported $[6,7,10,13]$.

Following a number of research results mainly in Indonesia are cited. In a field experiment [14] studying the effect of Bokashi 
and Sunn hemp (Crotalaria juncea L.) on maize (Zea mays L.) production and inorganic fertilizer efficiency in Alfisol. They found that application of Bokashi, Sunn hemp and combination of (Bokashi+Sunn hemp) along with inorganic fertilizer increased the yields of maize concluding that the use of organic fertilizer may reduce for about $50 \%$.

The study of [10] shown that the use of Bokashi fertilizers in a marginal soil could improve soil chemical properties. They found that Bokashi of burned-rice husk and bokashi sago dregs increased production of soybean (Glycine max L.). Hence, they recommended that Bokashi could be applied as the soil amendments for traditional farmers who cultivated plant in marginal farmland. Bokashi made from biomass of secondary vegetation has been found to increase the production of maize and peanut (Arachis hypogaea L.) suggesting that Bokashi could be potentially to reduce the cost of using chemical fertilizers [13].

The addition of Bokashi of water hyacinth (Eichhornia crassipes) was reported could provide a better soil condition for growth and production of soybean, corn and rice grown in dry land soil [15]. Combination of LCC (Legume Cover Crops: Centrosema pubescens, Calopogonium mucunoides and Pueraria javanica) and Bokashi had a significant effect on raising C-Organic, $\mathrm{P}$ and $\mathrm{K}$ of soil along with the increasing of Fe and Mn uptake by LCC [16]. Application of Bokashi cow-manure coupled with NPK inorganic fertilizer increased significantly soil Corganic, $\mathrm{N}$-fixing bacteria, P-solubilizing bacteria and bulb production of shallot (Allium ascalonicum) [17].

In an experiment of [11] found that the addition Bokhasi of cow-dung had the best dosage on the use of $8 \mathrm{t} \mathrm{ha}^{-1}$ resulting $20.4 \mathrm{t}$ $\mathrm{ha}^{-1}$ of the dry milled grain. Application of Bokashi made from green plant improved significantly the growth (height, diameter and number of leaf) and yield (diameter, length and weight of cob) of maize grown in an acid soil [12]. In this experiment, the use of Bokashi could raise up to $80 \%$ the cob-unhusk weight of maize.

\section{Conclusion}

It is clear that the use of Bokashi has contributed to improve soil fertility providing a better plant growth and production. In more essential practical advantages, the use of Bokashi could be adopted as a cheap technology due to low cost, safe, effective, abundance resources and adaptable to farmers on managing agricultural and environmental practices. However, elucidation on the method and mechanistic base of Bokashi is required for future research.

\section{References}

1. Higa T, Parr JF (1994) Beneficial and effective microorganisms for a sustainable agriculture and environment. International Nature Farming Research Center Atami, Japan, p. 16.
2. Ndona RK, Friedel JK, Spornberger A, Rinnforner T, Jezik K (2011) Effective micro-organisms' (EM): An effective plant strengthening agent for tomatoes in protected cultivation. Biological Agriculture and Horticulture 27(2): 189-203.

3. Olle M, Williams IH (2013) Effective microorganisms and their influence on vegetable production - a review. Journal of Horticultural Science \& Biotechnology 88(4): 380-386.

4. Iriti M, Scarafoni A, Pierce S, Castorina G, Vitalini S (2019) Soil Application of effective microorganisms (EM) maintains leaf photosynthetic efficiency, increases seed yield and quality traits of bean (Phaseolus vulgaris L.) plants grown on different substrates. International Journal of Molecular Sciences 20(9): 1-9.

5. Wakui Y (2009) Organic Farming Technology in Japan. Pilot Project for Better Farm Income by Organic Based Vegetable Production. p. 34.

6. Boechat CL, Santos JAG, Accioly AMA (2013) Net mineralization nitrogen and soil chemical changes with application of organic wastes with 'Fermented Bokashi Compost'. Acta Scientiarum. Agronomy Maringá 35(2): 257-264.

7. Pandit NR, Schmidt HP, Mulder J, Hale SE, Husson O, Cornelissen G (2019). Nutrient effect of various composting methods with and without biochar on soil fertility and maize growth. Archives of Agronomy and Soil Science, p. 17.

8. Merfield CN (2013) Treating food preparation 'waste' by Bokashi fermentation vs. composting for crop land application: A feasibility and scoping review. Lincoln, New Zealand: The BHU Future Farming Centre. p. 23.

9. Yamada K, Xu HL (2001) Properties and applications of an organic fertilizer inoculated with effective microorganisms. Journal of Crop Production 3(1): 255-268.

10. Wijayanto T, Zulfikar, Tufaila M, Sarman AM, Zamrun M (2016) Influence of bokashi fertilizers on soil chemical properties, soybean (Glycine max (L.) Merrill) yield components and production. WSEAS Transactions on Biology and Biomedicine (13): 134-141.

11. Silea LOMJ, Ginting S, Mamma S, Safuan LO (2017) The agronomic response of the dry rice toward fertilized plantation on wetland. AAB Bioflux 9(1): 47-56.

12. Ginting S, Hemon T, Syaf H, Faad H, Padangaran A (2019) Application of organic materials to improve the growth and yield of maize (Zea mays L.) in an acid soil of Southeast Sulawesi (submitted for publication).

13. Karimuna L, Rahni NM, Boer D (2016) The Use of bokashi to enhance agricultural productivity of marginal soils in Southeast Sulawesi, Indonesia. Journal of Tropical Crop Science 3(1): 1-6.

14. Yuliana AI, Sumarni T, Islami T (2015) Application of baokashi and sunn hemp (Crotalaria juncea L.) to improve inorganic fertilizer efficiency on mize (Zea mays L.). J Degrade Min Land Manage 3(1): 433-438.

15. Asrijal, Musa Y, Upe A, Ibrahim B, Rahmawati (2018) The Use of Bokashi-water hyacinth (Eichhornia crassipes) by single and multiple cropping systems of the soybean, corn, and dry land rice. International Journal of Science and Research 7(5): 148-152.

16. Prayogo C, Ihsan, M (2018) Utilization of LCC (Legume Cover Crop) and bokashi fertilizer for the efficiency of Fe and Mn uptake of former coal mine land. J Degrade Min Land Manage 6(1): 1527-1537.

17. Lasmini SA, Nasir B, Hayati B, Edy N (2018) Improvement of soil quality using bokashi composting and NPK fertilizer to increase shallot yield on dry land. Australian Journal of Crop Science 12(11): 1743-1749. 
DOI: 10.19080/IJESNR.2019.21.556070

Your next submission with Juniper Publishers will reach you the below assets

- Quality Editorial service

- Swift Peer Review

- Reprints availability

- E-prints Service

- Manuscript Podcast for convenient understanding

- Global attainment for your research

- Manuscript accessibility in different formats (Pdf, E-pub, Full Text, Audio)

- Unceasing customer service

Track the below URL for one-step submission https://juniperpublishers.com/online-submission.php 